\title{
Programa de Cidades Históricas (PCH) no âmbito das políticas culturais dos anos 1970: cultura, planejamento e nacional desenvolvimentismo
}

\author{
Márcia Chuva ${ }^{1}$ \\ Laís Villela Lavinas ${ }^{2}$
}

RESUMO: Este artigo analisa o Programa de Cidades Históricas (PCH) como parte da rede de relações e de poder que implementou as políticas culturais nos anos 1970 no Brasil, de modo integrado ao setor econômico do governo, com base nas linhas do projeto desenvolvimentista orientadas para o regionalismo associado à descentralização. Apresenta, inicialmente, documentos oficiais que orientaram a formulação da Política Nacional de Cultura na década de 1970 e a rede de intelectuais envolvidos na sua elaboração, contemplando diferentes agências do Estado, historicamente atuantes no campo da cultura. Destaca em tais documentos a naturalização da associação entre turismo, cultura e patrimônio, via pela qual se deu a incorporação do campo da cultura nas discussões sobre o desenvolvimento socioeconômico brasileiro. Analisa as parcerias estabelecidas entre o MEC e a Secretaria de Planejamento da Presidência da República para a criação e implantação do PCH, compreendido como um projeto de ações interministeriais integradas. Busca evidenciar os modos de incorporação das políticas culturais nos planos de desenvolvimento do Brasil Grande e apontamos a complexificação das redes e das representações acerca dos valores da brasilidade associados ao tradicional popular nordestino. Foram trazidas para a análise memórias de protagonistas do alto escalão do regime militar e de técnicos que compartilharam vivências, relacionadas àquela conjuntura e ao próprio PCH, cotejadas com uma diversificada documentação.

PALAVRAS-CHAVE: Programa de Cidades Históricas. Políticas Culturais no Brasil. Patrimônio Cultural. Nacional Desenvolvimentismo. Regime Militar.

ABSTRACT: The article analyzes the Program of Historical Cities - PCH (Programa de Cidades Históricas) as part of the network of relations and power that implemented cultural policies in the 1970s in Brazil, in an integrated manner to the government's economic sector, based on the lines of development project, oriented to a regionalism associated with decentralization. It presents first official documents that guided the formulation of the National Cultural Policy in the 1970s and the intellectual network involved in its preparation, comprising officers from different state agencies, historically active in the cultural field. The article highlights the naturalization of
1. Professora do Departamento de História e do Programa de PósGraduação em História da Universidade Federal do Estado do Rio de Janeiro (PPGH-UNIRIO) e do Mestrado Profissional em Patrimônio Cultural do Instituto do Patrimônio Histórico e Artístico Nacional - PEP-IPHAN. Email: <marciachuva@ gmail.com $>$.

2. Mestre em História pelo Programa de PósGraduação em História da Universidade Federal do Estado do Rio de Janeiro (PPGH-UNIRIO). Email: <lalalavinas@gmail.com>. 
3. Para o assunto, ver Carlos Fico (1997).

4. O livro, publicado pela editora Difel reúne textos apresentados no seminário "Estado e Cultura no Brasil. Anos 70", realizado pelo Instituto de Estudos Econômicos Sociais e Políticos de São Paulo (IDESP) em convênio com a Fundação Nacional de Arte, no segundo semestre de 1982. Miceli participou também da pesquisa "Estado e Cultura na Década de 70 (Diagnósticos das Instituições Públicas Federais)" em colaboração com a Professora Maria do Carmo Campello de Souza, igualmente financiada pela Funarte. Para maiores informações, ver Caio Gonçalves Dias (2014). the association between tourism, culture and heritage and the inclusion of the cultural field in the discussions about the Brazilian socioeconomic development. It analyzes partnerships between the Ministry of Education and Culture and the Secretariat of Planning of the Presidence of the Republic (Secretaria de Planejamento da Presidência da República) for the creation and implementation of the $\mathrm{PCH}$, understood as a project of integrated ministerial actions. We identify the ways of incorporation of cultural policies in development plans of the ideological program called "Great Brasil" (Brasil Grande), and pointed out the complexity of networks and representations about the Brazilianness values associated with the traditional folk Northeastern. We brought for analysis the memories ofhigh-ranking military regime protagonists and technicians who shared experiences related to the $\mathrm{PCH}$, and collated them with a diverse documentation.

KEYWORDS: Program of Historical Cities. Cultural Policies in Brazil. Cultural Heritage. National Development. Military Regime.

Introdução

Em 1973, foi formulado o documento "Políitica Nacional de Cultura: Diretrizes", mesmo ano em que foram criados o Programa Integrado de Reconstrução das Cidades Históricas, conhecido como PCH, e o Programa de Ação Cultural, o PAC. O PCH e o PAC podem ser entendidos como as duas grandes frentes das políticas culturais brasileiras do regime militar nos anos 1970, e uma de suas finalidades era estimular o desenvolvimento da indústria turística nacional. Enquanto - PCH seria a frente de recuperação e/ou criação de infraestrutura ambiental e física, o PAC se constituiria como o viés responsável pela dinâmica do produto cultural nacional. Juntos, os programas deveriam criar condições de estruturar circuitos turísticos regionais baseados na história, nos aspectos ambientais e nas manifestações artísticas e folclóricas. Ambos foram ampliando suas atribuições, expandindo seus territórios de atuação e de influência doutrinária dentro das políticas culturais federais até serem institucionalizados, por meio da sua incorporação por um órgão público cultural. Ambos tiveram apoio do Ministério do Planejamento, integrando as políticas culturais nos planos desenvolvimentistas do Brasil Potência ou Brasil, Grande, noções exploradas por diversos agentes e setores inseridos no Estado autoritário, que compartilhavam visões de mundo como ideólogos do regime. Configuradas no imaginário social do país, ao longo do processo de construção do Estado-nação, essas noções tinham por base a crença de que o Brasil se tornaria uma potência mundial devido à abundância de recursos naturais e a amplitude do território nacional ${ }^{3}$.

O apoio de João Paulo dos Reis Veloso e Severo Fagundes Gomes, respectivamente ministros do Planejamento e da Indústria e Comércio, especialmente no governo do General Ernesto Geisel, contribuiu para a expansão significativa dos dois programas, complexificando a trama de relações e comprometimentos que se delineava no campo cultural. Para analisar esse aspecto, tomamos por referência inicial a publicação, Estado e Cultura no Brasil, organizada por Sérgio Miceli, em 1984, que inaugura as reflexões acerca das políticas culturais no regime militar ${ }^{4}$. 
Ao nos debruçarmos sobre as políticas culturais dos anos 1970 que englobavam o PCH, três evidências se colocaram: o recorrente uso da palavra democracia em documentos oficiais do regime militar, inclusive na Política Nacional de Cultura: Diretrizes; a identificação da reincidência dos erros ocorridos no desenvolvimento do PCH em programas públicos subsequentes de natureza similar, como o Programa Monumenta e o recente Programa de Aceleração do Crescimento em Cidades Históricas - PAC ${ }^{5}$, ambos analisados por Márcia Sant'Anna ; e o apagamento do papel desempenhado pelo arquiteto Renato Soeiro, sucessor de Rodrigo Melo Franco de Andrade à frente do Iphan, cargo que ocupou por 10 anos.

Buscaremos neste artigo interpretar essas evidências a partir de três questões. A primeira delas, de natureza histórica, acerca das apropriações do conceito de democracia no contexto daquele regime, entendendo que tais apropriações não se colocavam necessariamente de maneira estratégica, com a finalidade de legitimar o regime, mas como visão de mundo dos intelectuais envolvidos 7 . Veremos então o PCH participar das políticas culturais nos anos 1970, de modo integrado ao setor de planejamento do governo, seguindo as linhas do projeto desenvolvimentista que se orientaram para o regionalismo associado à descentralização, por meio das redes de confiança e sociabilidade de intelectuais que não se confrontaram com militares ligados ao regime. Destacaremos também uma questão de natureza teórica, relativa ao conceito de Estado que embasa a interpretação das políticas culturais (e do PCH) como parte do processo de modernização autoritária do Estado implementada pelo regime militar - que aprofundou as relações capitalistas no Brasil e complexificou o Estado e a integração de redes sob seu controle. Veremos, na concretização do PCH, a naturalização da associação entre cultura e turismo, de tal forma reproduzida nos diversos documentos dos dois setores (cultura e turismo) que se apresentou como caminho natural para o desenvolvimento da região Nordeste, então em foco. E, por fim, colocamos uma questão de natureza historiográfica capaz de explicar o surgimento da versão que se tornou vigente no início dos anos 1980 sobre um Iphan decadente e enfraquecido, que promoveu o esvaziamento da gestão de Renato Soeiro, buscando apontar evidências do seu papel fundamental nesse período.

As fontes privilegiadas neste artigo foram documentos oficiais sobre as políticas culturais produzidos no período, ao lado de quatro entrevistas de diferentes naturezas, realizadas em tempos distintos. São elas, em ordem cronológica, a matéria que sintetizava a entrevista concedida por Severo Gomes à Revista Visão, em 1976, com o pretexto de divulgação do Centro Nacional de Referência Cultural; as entrevistas de Ernesto Geisel e João dos Reis Velloso publicadas em 1997 e 2004, respectivamente, que integram o Projeto de História Oral do CPDOC/FGV; e, por fim, a entrevista concedida por Antônio Carlos de Carvalho, em 2013, no âmbito de projeto de pesquisa sobre políticas culturais, turismo e patrimônio nos anos 1970-808. Pretendemos, por meio delas, fazer contato com memórias de pessoas que protagonizaram acontecimentos e compartilharam conjunturas, não para encontrar verdades obscurecidas, mas para fazer uma aproximação do objeto em investigação e cotejar com a documentação reunida.
5. O Programa Monumenta (1996-2010), voltado para a recuperação de cidades históricas brasileiras, desenvolveu-se com o acompanhamento do Iphan e teve o Banco Interamericano de Desenvolvimento (BID) como agente financiador. Em 2013, o Ministério do Planejamento autorizou a criação de uma linha de financiamento destinada exclusivamente aos sítios históricos urbanos protegidos pelo Iphan, dando origem ao PAC Cidades Históricas. Informação extraída no $<$ http://portal.iphan.gov.br/ pagina/detalhes/235>, acesso em 23 dez. 2015.

6. Na sua conferência de abertura do Seminário $\mathrm{PCH}$ : 40 anos, Márcia Sant'Anna dedica-se a analisar essa constatação e interpreta alguns efeitos de tais programas como "erros recorrentes". Nossa interpretação é de que tais recorrências são efeitos dos programas, mas não necessariamente "erros" .

7. Entendemos aqui apropriação no âmbito da recepção como criação pertencente à própria dinâmica social, que coloca em movimento relações em meio a diferentes interesses em jogo. Ver Pierre Bourdieu (1982).

8. Antônio Carlos de Carvalho trabalhou na Embratur de 1972 a 1977. Ocupou os cargos de chefe do Departamento de Programas e Projetos e chefe do Departamento de Patrimônio Turístico Nacional, ambos da Diretoria de Planejamento da Embratur. Atualmente é professor aposentado do Departamento de Turismo da Unirio e concordou em contar um pouco sobre suas memórias de atuação na Embratur, no âmbito do projeto de pesquisa em andamento sobre Relações 
entre Patrimônio e Turismo nas políticas culturais dos anos 1970-1980 no Brasil, coordenado pela professora Leila Bianchi Aguiar. A entrevista foi feita em junho de 2013, no Programa de Pós-graduação em História Social da UNIRIO, e contou com a participação de Leila Bianchi Aguiar, Márcia Chuva e Laís Villela Lavinas.

9. Ver Marcia Sant'Anna (1995); Sandra Rafaela Magalhães Correa (2012).

10. Para Nestor Garcia Canclini, política pública no âmbito da cultura é o conjunto de intervenções realizadas pelo Estado, as instituições civis e os grupos comunitários organizados, a fim de orientar o desenvolvimento simbólico, satisfazer as necessidades culturais da população e obter consenso para um tipo de ordem ou transformação social. Ver Nestor G. Canclini (2001, p. 65).

11. Cf. Boaventura de Sousa Santos (2007, p. 71).

12. Afonso Arinos também fazia parte do Conselho Consultivo do Iphan. Para maiores informações sobre o Conselho Federal de Cultura durante o regime militar, ver Tatyana do Amaral Maia (2010; 2012).

13. APAM-FUNDAJ (Arquivo Persona Aloísio Magalhães da Fundação Joaquim Nabuco). Referência: PIp15doc73c.

14. O documento de 1975 foi solicitado ao grupo de trabalho criado pelo ministro Ney Braga, formado por: Afonso Arinos de Mello Franco, Gilberto Freyre, Roberto Parreira, Manuel Diegues Júnior, Renato Soeiro, como se pode ver no Discurso de Ney Braga, publicado no Boletim do CFC, Rio de Janeiro, n. 23, 1976. Para Gabriel Cohn, no artigo publicado no livro Estado e Cultura no Brasil organizado
O PCH entre diretrizes de preservação e desenvolvimento: redes e concepções

Historicamente, há continuidades e rupturas importantes no âmbito das políticas de patrimônio nos anos 1970\%. Destacamos uma ruptura significativa em relação às políticas culturais que vigeram desde os anos 1930, no regime varguista, e que tornou as políticas de patrimônio políticas públicas ${ }^{10}$.

Por sua vez, verificamos a persistência do pensamento moderno, se analisamos conforme a perspectiva de Boaventura Sousa Santos. Para ele, "o pensamento moderno ocidental é um pensamento abissal (...) capaz de colocar na invisibilidade existências, criar ausências. (...) A característica fundamental do pensamento abissal é a impossibilidade da co-presença dos dois lados da linha." 11. Isso indica a crença de que há apenas um saber a ser compartilhado e, portanto, alguns privilegiados devem ensinar para outros que precisam aprender. Um dos lados da linha terá que aprender com o outro lado. É justamente nesse papel que veremos os intelectuais envolvidos nas políticas culturais aqui em análise.

A Modernidade criou também o conceito de democracia como conhecemos hoje. Embora seja uma palavra de sentido claro e objetivo à primeira vista, as apropriações que dela têm sido feitas historicamente revelam ambiguidades e leituras bastante distintas, mostrando tratar-se de um termo polissêmico e/ou polivalente. Entendemos que esse modo de pensar moderno deve ser transformado, sem se abrir mão, contudo, da democracia como um valor. Quais seriam as apropriações do conceito de democracia nas políticas culturais em que o PCH foi construído e quais os seus efeitos?

O PCH fez parte da rede de relações e de poder integrada ao projeto desenvolvimentista do governo militar baseado no binômio regionalismo e descentralização, e que implementou as políticas culturais nos anos 1970 no Brasil. Entendia-se que por meio desse binômio seria garantido o acesso a bens culturais até então centralizados no Sudeste brasileiro, e justamente essa oportunidade de acesso foi interpretada como sinônimo de democracia. Vejamos.

O documento intitulado "Política Nacional de Cultura: Diretrizes" delineou as bases das políticas culturais dos anos 1970. A pedido do Ministro da Educação e Cultura, Jarbas Passarinho (1969-1974), o documento foi escrito pelo conselheiro Afonso Arinos de Melo rranco $^{12}$ e apresentado pelo Conselho Federal de Cultura em 197313. Segundo Gabriel Cohn, a elaboração desse documento foi marcada por pressões e tensões dentro do MEC e em outras instâncias federais que acabaram por engavetá-lo, motivo pelo qual foi suspensa a sua publicação. Dois anos depois, em 1975, tais pressões estavam amenizadas e foi lançada a "Política Nacional de Cultura", versão requentada/ nuançada do documento de 1973, apresentada pelo mesmo Conselho Federal de Cultura, a partir da demanda do novo ministro da pasta, Ney Braga (19741979)14. 
Os objetivos da "Política Nacional de Cultural: diretrizes" eram:

São três os objetivos básicos da política a ser implementada. $\bigcirc$ primeiro deles é a preservação do patrimônio cultural, tendo por meta conservar o acervo constituído e manter viva a memória nacional, assegurando a perenidade da cultura brasileira. Segue-se o incentivo à criatividade que visa dar ao homem brasileiro, no domínio cultural, a plena utilização de seu potencial inventivo. Cumpre, por fim, assegurar a difusão das criações e manifestações culturais, por um mecanismo que facilite o conhecimento e a apreensão de seu significado pelo povo, tendo como consequência natural um processo de retorno e enriquecimento ${ }^{15}$.

Para cumprir tais objetivos, o documento sugere a tomada de medidas fundamentais, como a descentralização das ações, a promoção do turismo e aquelas que aliem cultura e educação. Tais medidas são reincidentes em diferentes documentos do campo cultural da década de 1970, e constarão claramente dos objetivos do $\mathrm{PCH}^{16}$.

Segundo o documento, o Estado deveria garantir acesso, desfrute/ fruição e criação da produção cultural, com o intuito de educar/ensinar a população. Nesses termos, cultura era:

Admitida lato sensu como somatório das criações do Homem, no prosseguimento da obra da própria Criação, todos, a todo tempo, participam de sua formação e desenvolvimento, enquanto a justiça social reclama que os seus benefícios sejam acessíveis ao cidadão comum, e este adequadamente educado para usufruíto ${ }^{17}$.

documento fazia assim uma crítica a uma dada concepção de cultura: "não são mais admissíveis os conceitos que a [cultura] situam como o produto da criatividade de elites e seu patrimônio" 18, que teriam orientado as ações no setor em décadas anteriores. Verificamos, contudo, que o documento não fugiu da conexão entre cultura e formação da nação que se construiu, desde os anos 1930, na gestão de Gustavo Capanema à frente do Ministério da Educação e Saúde, no governo Vargas, especialmente durante o Estado Novo, tendo em vista que, do mesmo modo, era preciso civilizar o cidadão para que fosse capaz de usufruir da cultura $^{19}$. Como veremos a seguir, aquilo que havia sido percebido como elitista - tal como o patrimônio edificado mineiro colonial até então valorizado como máxima representação da brasilidade - foi acrescido de outros valores, como aqueles que representassem o tradicional popular, regional, nordestino, ampliandose o universo de bens, ainda que as escolhas permanecessem nas mãos das elites políticas e intelectuais, agora com vínculos regionais.

Intelectuais com vínculos com elites culturais do Nordeste se aproximaram do projeto político desenvolvimentista do II PND e, a partir deles, representações acerca de uma identidade cultural (popular) nordestina ganharam caráter nacional. As noções de cultura e identidade regionais difundidas pelo regionalismo nordestino "da saudade", como tratou Durval Albuquerque Junior20, foram incorporadas nos discursos da memória nacional, graças à expressiva ação da rede de intelectuais por Sérgio Miceli, em 1984, os dois documentos têm fundamentos doutrinários semelhantes, tendo sido ambos escritos com a chancela do Conselho Federal de Cultura, e com participação de quadros do MEC. Para o assunto, ver também Caio Gonçalves Dias (2014).

15. Cf. Conselho Federal de Cultura (1973, p.713). Grifos no original.

16. A reincidência de discussões, reflexões e planejamento de atuação envolvendo as temáticas mencionadas podem ser verificadas em diversos documentos orientadores das políticas culturais brasileiras ao longo da década de 1970 e 1980, tais como a Política Nacional de Cultura (1975); documento apresentado pelo Secretário da Cultura na reunião de Coordenação Geral do MEC (1981); definições para a operacionalização da Política Cultural (1981); Relatório da Comissão Parlamentar de Inquérito destinada a investigar a situação do patrimônio histórico e artístico nacional e avaliar a política do governo federal para sua defesa e conservação (1982).

17. Cf. Conselho Federal de Cultura (1973, p.711).

18. Ibidem

19. Para o assunto, há vasta bibliografia, a exemplo de José Reginaldo Gonçalves (1996), Angela de Castro Gomes (1998) e Márcia Chuva (2009, 2011).

20. Ver Durval de Albuquerque Junior (2009). 
21. Ver Rodrigo Patto Sá Motta (2014) e Francisco Carlos Teixeira da Silva (2000).

22. Ver Lia Calabre (2009).

23. Ver Sérgio Miceli (1984).

24. Ver Maria Cecília Londres Fonseca (1997). nordestinos. Alguns deles já tinham inserções variadas, desde os anos 1940, nas malhas da burocracia do Estado brasileiro - a exemplo de Gilberto Freyre e Ariano Suassuna, membros do Conselho Federal de Cultura e colaboradores de instituições públicas de cultura, como a Fundação Joaquim Nabuco; João Cabral de Melo Neto, diplomata cassado por Getúlio Vargas em 1953, reassumindo o posto em 1954, tornando-se em 1968, membro da Academia Brasileira de Letras; além do próprio Renato Soeiro, especialmente no campo da cultura. Por meio de sua ação nesse novo contexto, as especificidades socioculturais nordestinas eram integradas às raízes culturais brasileiras como uma espécie de conversão. Seria essa elite, letrada e ligada historicamente a agências da sociedade política, porta voz do povo? $\bigcirc$ binômio descentralização e regionalismo, tão caro ao $\mathrm{PCH}$, tornou-se sinônimo de acesso e esse, como vimos, sinônimo de democracia. O PCH colocava em prática essas ideias com as medidas voltadas para a descentralização, compreendida como ampliação do acesso a bens culturais e incorporação de novos valores na barca da cultura nacional. Contudo, não estava no horizonte do programa fomentar a participação da população, e sim promover a melhoria da qualidade de vida, conforme o entendimento de seus gestores.

O PCH inova ao constituir uma política integrada, isto é, estruturada a partir do diálogo entre diferentes setores do governo, como a Seplan, ou o próprio Iphan e os organismos estaduais com setores privados. Compreendemos essa participação não propriamente como democratização das políticas públicas, mas como estratégia de incorporação, pelo Estado, dos conflitos de interesses que se encontravam dispersos na sociedade civil, circunscrevendo-os sob suas rédeas, dentro da própria estrutura do Estado.

Se analisarmos os modos de implantação das políticas culturais no período, especialmente a partir do $\mathrm{PCH}$, verificamos que elas estavam perfeitamente inseridas no padrão de modernização autoritária que foi implantado à época e que promoveu um aprofundamento do capitalismo no Brasi|21, associando modernização e repressão. Desse modo, vamos de encontro às teses que enfatizam a perspectiva das políticas culturais como estratégia de abrandamento do regime visando a sua legitimidade. Tais teses, em geral, apontam medidas adotadas no sentido de integrar intelectuais e de apresentar uma imagem suavizada do regime.

Em relação ao primeiro aspecto, Lia Calabre 22 demonstra como o programa de distribuição e promoção de filmes brasileiros no exterior e a realização de festivais de cinema pelo país exerceram papel fundamental na integração entre intelectuais, artistas e militares no setor público cultural do Estado brasileiro.

Sobre o segundo ponto, para Sérgio Miceli23, o governo preocupava-se em melhorar sua imagem nas diretrizes de condução da abertura políitica, nas quais se incluíam medidas de descentralização do acesso à produção cultural. Também a valorização da pluralidade cultural e do desenvolvimento da cultura popular

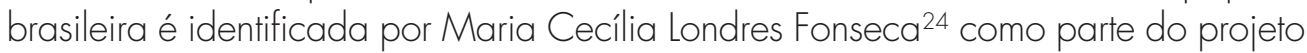
nacional, não necessariamente relacionado à segurança nacional. 
Menos que desconstruir essas leituras, nossa perspectiva visa observar essas ações no plano cultural como parte constituinte e coerente do projeto desenvolvimentista que se estrutura graças à modernização autoritária em curso. Nessa linha, vale lembrar que esse mesmo regime montou uma estrutura institucionalizada de censura e repressão para controle e investigação de seus próprios funcionários, que atingiu também o Ministério da Educação e Cultura ${ }^{25}$.

○ PCH foi, sem dúvida, a um só tempo resultante e incentivador da estruturação e da dinamização do setor empresarial da construção civil. Os impactos da industrialização que vinha se processando desde os anos 50 são acelerados no regime militar, atingindo diversas frentes. Nesse sentido, as proposições do PCH envolviam planejamento urbano e atingiam outro setor empresarial em formação, o turístico.

Observando ainda o documento da "Política Nacional de Cultura: diretrizes", verificamos que a preservação da cultura tornou-se uma questão de segurança nacional ${ }^{26}$, aspecto que até então não havia sido elaborado nesses termos. A defesa da cultura era comparada à "defesa do território, dos céus e dos mares pátrios" 27, pois "contribui para a formação e a identificação da personalidade nacional" e visava "edificar uma sociedade aberta e progressista"28. Aliar desenvolvimento e cultura como medidas estratégicas relacionadas à segurança nacional foi posto claramente nesse documento, ao lado da noção de Brasil Grande aqui subentendida:

Na estratégia do desenvolvimento, que é a grande aspiração que comove a alma brasileira e mobiliza a potencialidade nacional, a intensificação das atividades culturais está chamada a representar uma das ações fundamentais. (...) É necessário que, do mesmo passo, desenvolva uma cultura vigorosa, capaz de emprestar-the personalidade nacional forte e influente. Nesse rumo de concepções e na conformidade de nossa vocação democrática, a Política Cultural entrelaça-se, com áreas de recobrimento, às Políticas de Segurança e Desenvolvimento, e substancialmente significa a presença do Estado, como elemento de apoio e estímulo - que não se confundirá com coerção ou tutela - à integração do desenvolvimento cultural dentro do processo global do desenvolvimento brasileiro 29 .

A "vocação democrática" brasileira, concebida em tempos de ditadura, significava uma forte intervenção do Estado no setor cultural, não como "coerção ou tutela", mas como "apoio e estímulo", palavras cujos significados só podem ser compreendidos em contexto. As áreas de recobrimento seriam aquelas de atuação conjunta da política cultural e das políticas de segurança e desenvolvimento. $\bigcirc$ $\mathrm{PCH}$, como veremos, será excelente exemplo de aplicação dessa ideia de interseção. "Política Nacional de Cultura: diretrizes" foi, efetivamente, o primeiro documento expressivo do Conselho Federal de Cultura, que havia sido criado em 1966. No campo das políticas culturais, circularam antes dele, em 1970 e 1971, dois documentos tratando da atuação da cultura no desenvolvimento socioeconômico do país, frutos dos dois Encontros de Governadores, realizados em Brasília e Salvador. $\bigcirc$ "Compromisso de Salvador" buscou uma associação do turismo com
25. Isso pode ser verificado em documentos como: Arquivo Nacional, BR_AN_ BSB_AA1_LGS_018; Diário Oficial da União de 16 de abril de 1969 , seção I, parte I. Apresenta o regimento da Divisão de Segurança e Informações do MEC. A rquivo C N V, 00092.000097/2014-82; "Diretriz de Segurança Interna", 1968. Arquivo CNV, 00092.000775/201245; Ligações Funcionais dos Órgãos do Sistema Setorial de Informações do Ministério da Educação e Cultura - Normas Reguladoras - $\mathrm{n}^{\circ} 1 / 77$ Documento assinado por Armando Menezes, diretor da DSI/MEC, 1977.

26. A ideologia da Segurança Nacional durante o regime militar teve seus princípios básicos formulados pela Escola Superior de Guerra e serviu como amparo fundamental para o discurso de legitimação do golpe de 1964. Além de ser utilizada como justificativa para a continuidade do regime. Para saber mais, ver Carlos Fico (2004).

27. Cf. Conselho Federal de Cultura (1973).

28. Idem. São eles o Compromisso de Brasília (1970) e o Compromisso de Salvador (1973).

29. Cf. Conselho Federal de Cultura (1973, p.712). Grifo nosso. 
30. "Independente e autêntico" quer dizer, nesse contexto, sem influência estrangeira. A expressão "autêntico" está presente em diversos documentos, como um valor a ser reconhecido contra a homogeneização cultural, causada pelo processo de industrialização acelerado, vista como esterilizante dos aprendizados criativos das sociedades locais. Um exemplo dessas ideias é a entrevista de Severo Gomes à Revista Visão. A fotocópia dessa matéria encontra-se em Correspondência Passiva com Aloísio Magalhães. Ver Ernani Teixeira Filho (1976). No campo cultural o termo "autêntico" ganha especial destaque e foi analisado por José Reginaldo Gonçalves (1988; 1996).

31. Compromisso de Salvador, 1971. Cf. Iphan (1973).

32. Dentre elas, podemos destacar a parceria do MRE na criação da Comissão Nacional de Folclore, em 1947, com a liderança de Renato de Almeida, ligado ao Instituto Brasileiro de Educação, Ciência e Cultura (IBECC), Comissão Nacional da UNESCO bem como nos processos de saída de obras de arte do país atendendo aos preceitos do Decreto-lei $25 / 1937$, que organizou as atribuições do Sphan.

33. Por meio da Lei $\mathrm{n}^{\circ} 6.036$ de 1 de maio de 1974, o Ministério do Planejamento passa a ser uma secretaria ligada à Presidência da República, criada no governo Geisel a partir da reforma administrativa iniciada por Hélio Beltrão em 1968. Ver Celso Castro; Maria Celina D'Araujo (2004).

34. Nessa entrevista, João Reis Velloso trata dos 10 anos que esteve à frente da pasta do planejamento (1969-1979), figura chave no Governo Militar. Ver Celso Castro e Maria Celina D'Araujo (2004). as políticas culturais e apontou também a conservação da dinâmica cultural como a chave para o desenvolvimento socioeconômico independente e autêntico ${ }^{30}$, que deveria se dar por meio do desenvolvimento de um turismo com viés preservacionista $^{31}$. Ali tornou-se explícita a necessidade do uso da cultura como meio para se atingir o reconhecimento internacional e, principalmente, o desenvolvimento pleno, no sentido do aprofundamento da modernização autoritária que se processava.

No âmbito internacional, o Ministério das Relações Exteriores (MRE) foi convocado para auxiliar o MEC a difundir a cultura nacional e promover o turismo internacional do país, setor empresarial em crescimento. Vale dizer que muitos diplomatas atuavam no campo da política cultural, como é o caso de Mario Gibson Barbosa, Renato de Almeida e João Cabral de Melo Neto e compuseram as redes de poder articuladas nos anos 1970, atualizando antigas parcerias do MRE com o setor cultural, que tinham lugar desde o período Vargas ${ }^{32}$

Para o desenvolvimento pleno almejado, foi lançado, no mesmo contexto dessas ideias, o II Plano Nacional de Desenvolvimento - II PND (1975-1979), instituído no governo Geisel, na gestão de João Reis Velloso à frente do Ministério do Planejamento, depois Secretaria de Planejamento da Presidência da República (Seplan) ${ }^{33}$. Ao lado da provecta parceria com o MRE, o setor cultural adequava-se às bases do II PND - momento em que ganhou maior visibilidade e atenção do setor do Planejamento.

Numa leitura a posteriori da sua participação naquele contexto, temos a entrevista concedida por João Paulo dos Reis Velloso a Maria Celina D'Araujo e Celso Castro, publicada em 2004 ${ }^{34}$. A centralidade estratégica do setor de planejamento é lembrada por Reis Velloso como uma conquista da sua orientação política. Ele conta que Ernesto Geisel, antes de sua posse como Presidente, o consultou

sobre o lugar que o Planejamento deveria ocupar na estrutura de governo. Se eu achava bom (...) como uma pasta ministerial. Respondi: "Não, presidente, acho que está errado. $\bigcirc$ Planejamento deve ser um órgão, uma secretaria da presidência da República, ou não deve existir. A função básica do Planejamento é ajudar o presidente na coordenação da política econômica e isso não pode ser feito sendo um órgão do mesmo nível dos outros ${ }^{35}$.

A Seplan tornou-se efetivamente uma espécie de centro das decisões econômicas do país e buscava promover programas, projetos e ações de políticas públicas baseados em uma perspectiva integracionista. Além da preocupação em viabilizar a integração regional do Brasil, existia uma sistemática metodológica de fomento também à integração ministerial, promovendo programas intersetoriais. Tornou-se grande financiadora de projetos voltados para organização e criação de infraestrutura nas regiões brasileiras. Foi, sem dúvida, na longa gestão de Reis Velloso que aumentaram as frentes de atuação do setor, com novas estratégias para dar autonomia e agilidade à utilização dos recursos financeiros, reunindo, sob seu controle, fundos para financiamento de projetos relacionados ao desenvolvimento 
tecnológico, científico e industrial. $\bigcirc$ Estado, assim, subsidiava com recursos públicos, setores empresariais como o turístico, sem que os efeitos fossem previsíveis para as populações locais, em boa medida carentes também dos serviços do Estado.

Para Geisel, o poder político de Reis Velloso ampliou-se, como mencionou em sua entrevista ${ }^{36}$ ao lembrar que Velloso tinha bom trânsito entre as classes intelectuais e artísticas brasileiras, sendo amigo pessoal de Eduardo Portella, Nelson Rodrigues, Glauber Rocha, Américo Jacobina Lacombe, José Paulo Moreira da Fonseca, Aloísio Magalhães e Afrânio Coutinho, alguns deles nomes de destaque no campo da educação e cultura, e com inserção nas elites políticas e intelectuais de estados do Nordeste (como Aloísio Magalhães, Glauber Rocha e Eduardo Portella). Eles compunham uma rede de intelectuais que não se confrontaram diretamente com o regime, e atuavam em diversos órgãos do Estado e/ou postos do governo. Segundo Miceli, verifica-se a formação de uma elite intelectualburocrática no Estado brasileiro, a partir de Vargas, com "...uma ampliação das carreiras reservadas aos intelectuais ao mesmo tempo que se intensifica o recrutamento de novas categorias de especialistas" ${ }^{37}$. No campo da política cultural, criou-se uma espécie de "intelligentsia" que passou a intervir em todos os setores de produção, difusão e conservação dos campos intelectual e artístico no país. Esse cenário teve continuidade no contexto do regime militar, em que boa parte daquela intelectualidade estava presente, matizado por características históricas que indicariam novos vínculos, especialmente com elites culturais e políticas do Nordeste.

Segundo Reis Velloso, o II PND redirecionou recursos do Ministério do Planejamento para o "desenvolvimento regional sob forma de áreas integradas (...), eram programas de pólos, áreas selecionadas"38, com foco no desenvolvimento socioeconômico das regiões Nordeste e Norte. Três programas foram estruturados como polos: o Programa de Desenvolvimento dos Cerrados (Polocentro), o Programa de Polos Agropecuários e Agrominerais da Amazônia (Polamazônia) e o Programa de Desenvolvimento de Áreas Integradas do Nordeste (Polonordeste), ao qual se vinculou o $\mathrm{PCH}$.

$\mathrm{Na}$ entrevista publicada em 2004, ao ser indagado sobre os investimentos de seu ministério nas políticas culturais, Reis Velloso lembra as iniciativas no âmbito da Embrafilme e em projetos de difusão cultural no Nordeste, apresentando como exemplos o projeto teatral de Nova Jerusalém e o movimento armorial lançado por Ariano Suassuna. Para Sérgio Miceli, a aproximação do setor do planejamento com o setor cultural, especialmente em projetos como esses ligados ao PAC e em áreas praticamente desassistidas pelos demais órgãos oficiais, tinha como finalidade não apenas abertura de linhas de crédito, mas uma "tentativa oficial de 'degelo' em relação aos meios artísticos e intelectuais" 39 . Se concordamos com Miceli, numa dada perspectiva, entendemos que essa finalidade estava associada aos interesses do capital hegemônico, e não aos setores subalternos locais, atingidos diretamente pelas ações, programas e medidas implantadas.
35. Cf. Celso Castro; Maria Celina D'Araujo (2004, p.156).

36. Ver Celso Castro; Maria Celina D'Araujo (1997).

37. Cf. Sergio Miceli (1979, p. 132).

38. Cf. Celso Castro e Maria Celina D'Araujo (2004).

39. Cf. Sérgio Miceli (1984, p. 55). 
40. As lutas de representação (ou lutas de classificação), entendidas como uma espécie de concorrência entre visões de mundo que almejam alcançar hegemonia e consenso, são operacionais para compreender o campo de forças em que se insere a problemática do patrimônio e a incorporação de uma gama de intelectuais nessa esfera da administração pública. Ver Pierre Bourdieu (1989).

41. Comissão Parlamentar de Inquérito criada com o objetivo de "Examinar o envolvimento de figuras da Administração Pública Federal, direta ou indiretamente, no favorecimento à empresa Quatro Rodas Hotéis do Nordeste e suas coligadas, de forma a causar eventuais prejuízos ao Erário Público". Cf. Arquivo Nacional, AC_ ACE_19770_81, p.7, 1981.

42. Cf. Arquivo Nacional, AC_ACE_19770_81, p.12, 1981.

43. Para uma leitura mais aprofundada sobre a histórica relação entre turismo e preservação cultural no Brasil, ver Leila Bianchi Aguiar (2006).

44. Para o assunto, ver Antonio Gramsci, em Carlos Nelson Coutinho (2011).
Ministério do Planejamento apoiava o PAC e o PCH, o que além de indicar que as políticas culturais faziam parte dos planos de desenvolvimento do Brasil Potência, também apontava para o fato de que elas tiveram expandidas, significativamente, suas tramas de atuação, complexificando os interesses e as lutas de representação no setor ${ }^{40}$.

O diretor do Banco Nacional de Habitação durante o início dos anos 1970, Rubens Vaz da Costa, em seu depoimento à Comissão Parlamentar de Inquérito (CPI) da Quatro Rodas Hotéis do Nordeste ${ }^{41}$, conta que

(...) a ênfase para o apoio do turismo não partia só do Poder Executivo. Ao discutir o II PND (Lei n 5727/71), o Congresso Nacional acrescentou a seguinte "Ressalva" n³: "O Plano deve incluir medidas que visem ao incremento do turismo, tanto de correntes turísticas internacionais, como internas, dotando-se as regiões propícias de condições favoráveis ${ }^{42}$.

Dentro das diretrizes de desenvolvimento socioeconômico descentralizado no âmbito do II PND, portanto, o turismo foi visto como um dos caminhos para o crescimento do Nordeste. Na legislação preexistente (o Decreto-lei n. 55/1966, que definiu a política nacional de turismo, criou o Conselho Nacional de Turismo e a Empresa Brasileira de Turismo), a cultura era apresentada como infraestrutura do turismo e serviria de base jurídica para a associação entre turismo e cultura, perspectiva presente na "Política Nacional de Cultura: diretrizes", que seria explorada pelo $\mathrm{PCH}$.

Assim, na medida em que a cultura ganhava espaço nas discussões sobre o desenvolvimento socioeconômico brasileiro, ao longo da década de 1970, de modo associado ao turismo, a Seplan tornava-se uma parceira recorrente nas políticas culturais federais. Os interesses ali em jogo, evidenciados nas falas de representantes de agências públicas em fóruns que envolviam agências privadas ligadas ao setor turístico em expansão, como a Quatro Rodas Hotéis do Nordeste e outras empresas a ela coligadas, indicam as lutas de representação que levariam ao reconhecimento da associação entre cultura, patrimônio e turismo como alternativa única para o desenvolvimento regional associado e, portanto, a saída "natural" para a preservação do patrimônio cultural ${ }^{43}$. Esse foi um dos fatores que permitiu a reconfiguração da amplitude das políticas culturais brasileiras, que conquistaram uma pasta ministerial exclusiva em 1985.

Para avançarmos na compreensão das "lições não aprendidas" e que parecem se repetir eternamente nos diversos programas voltados para cultura e desenvolvimento no âmbito do patrimônio urbano, conforme tratou Sant'Anna, propomos refletir sobre a modernização autoritária que se instalou nesse período, com base numa perspectiva de Estado ampliado ${ }^{44}$, por meio da qual abrem-se algumas chaves de compreensão, como, por exemplo, a participação dos setores beneficiados pelo programa, como o da construção civil. A soma de recursos em programas de patrimônio que se caracterizam, grosso modo, por executar obras é uma pista a ser verificada. Trata-se da lógica capitalista do Estado dominado por frações da classe dominante e que disputam, legitimamente, dentro do Estado, 
pelas prioridades e recursos, projetos etc.. $\bigcirc$ capitalismo empresarial sai extremamente fortalecido do regime - o que faz completo sentido em um contexto mundial de radicalismo político-ideológico dicotômico entre capitalismo e comunismo.

Não se trata, portanto, de afirmar que a pulverização de recursos ou a falta de planos de políticas locais são as causas para que tais programas fracassem recorrentemente, no sentido da preservação e de sua apropriação pela sociedade. Cabe perguntar em quais perspectivas eles efetivamente fracassaram ou "não deram certo", identificando o que fazia parte dos seus planos em execução. Segundo parece, tais planos seriam bem sucedidos na medida em que fossem capazes de alçar setores empresariais específicos, como o hoteleiro e o da construção civil, fortalecendo as relações das agências públicas e privadas que compõem o Estado ampliado. Nesse sentido e em vários outros apontados por Correa $^{45}$, o PCH foi um sucesso.

Uma malha burocrática dedicada às políticas culturais na região nordestina atendia às normas dos convênios com o PCH, que condicionavam a liberação de recursos apenas por meio de organismos culturais públicos ${ }^{46}$. Essa malha é constituinte desse Estado, como a burocracia que o complexifica e as políticas culturais, ampliando as redes. Ao mesmo tempo em que se dava uma reestruturação do Estado a nação se redesenhava, pois, como tratou Norbert Elias, ambos são parte de um mesmo processo ${ }^{47}$.

O depoimento de Roberto Parreira, responsável pelo Programa de Ação Cultural (PAC) até sua incorporação à Funarte em 1976, refere-se a uma concorrência intraburocrática, ao afirmar que a ação pontual do PAC seria uma forma de resistência à preferência pelo setor patrimonial dentro do MEC ${ }^{48}$.

$\bigcirc \mathrm{PCH}$ e o PAC se constituíram em programas de dinamização e de injeção de recursos no setor cultural. A burocracia de Estado também está posta em cena. Adotando uma dinâmica administrativa semelhante à de diversos outros programas governamentais, ambos investiram em forças tarefas de trabalho, em que se montavam equipes de acordo com as necessidades de cada projeto. Os profissionais participantes poderiam ser contratados como prestadores de serviço, o que não limitava o programa ao quadro de funcionários das instituições culturais públicas, precarizadas em recursos humanos e materiais naquele contexto, e contornava as regras de contratação do serviço público. Essa flexibilidade administrativa fez com que os dois programas agilizassem os projetos formulados no interior do DAC. O PAC, por exemplo, agiu pontualmente em setores artísticos de espetáculo, produzindo rápidos resultados. Destinava-se à expansão das políticas culturais, com recursos direcionados ao teatro, ao folclore, à música, a exposições de pinturas, balés e corais. Sérgio Miceli mostra que o PAC, aos poucos, fortaleceu uma frente de financiamento de espetáculos no MEC por meio dos recursos do Fundo Nacional de Desenvolvimento em Educação (FNDE), e passou a cobrir uma área do mercado cultural ainda não tocada pelas políticas culturais. Ampliava-se assim o campo de trabalho para artistas e movimentos
45. Ver Sandra Rafaela Magalhães Correa (2012).

46. Cf. tratado por Paulo Ormindo de Azevedo (2013).

47. Cf. tratado por Norbert Elias (1993).

48. Ver Roberto Parreira (1984). Depoimento publicado na coletânea organizada por Sérgio Miceli, em 1984, que reuniu vários gestores da cultura dos anos 1970. Para uma compreensão mais ampla dos debates em torno das políticas culturais nos anos 1980, ver Caio Dias (2014). 
49. Cf. Sérgio Miceli (1984, p. 68).

50. Cf. Arquivo Nacional, B R - D F A N B S B 2M_o_0_0497_0002_ d0001de0001. Documentos Recebidos na PR/EMFA durante o terceiro semestre de 1967. p.134. culturais regionais, pois se propunha a "operar em termos de um calendário de espetáculos em diversas áreas da produção cultural, a serem apresentados em todo o país, no intuito de incentivar o intercâmbio regional"49.

Apesar desse incentivo à produção cultural, manteve-se o notório predomínio da perspectiva preservacionista nas políticas culturais, em boa medida, garantido pelo PCH. Por meio dele, ampliaram-se, significativamente, as intervenções de conservação e restauração de bens arquitetônicos do âmbito das atribuições do Instituto do Patrimônio Histórico e Artístico Nacional (lphan).

Agentes, agências de turismo e patrimônio - questões para a historiografia

A realização do binômio regionalismo e descentralização também se processa no sentido da estruturação do Estado, e Renato Soeiro foi peça chave nesse contexto com seu protagonismo nas redes de agentes envolvidos com as novas diretrizes das políticas culturais, como veremos.

No período analisado, o arquiteto Renato Soeiro, funcionário do Iphan desde 1938, foi um agente social com expressiva atuação no MEC e manteve-se em diversas frentes políticas do campo da cultura. Ele foi diretor do Iphan, cargo que ocupou por 10 anos (1969-1979), tinha assento no CFC e no Conselho Consultivo do $\mathrm{PCH}$, além de ter dirigido o Departamento de Assuntos Culturais (DAC) - a autarquia-base dos programas PAC e PCH - até 1974, quando foi substituído por Manuel Diegues Júnior. Fora membro do Conselho Nacional de Turismo (CNTur), tendo feito parte do grupo de trabalho que elaborou o Plano Nacional de Turismo, datado de 1967. No mesmo ano, Soeiro participou da elaboração do "Anteprojeto de Lei do Plano de Metas da Cultura Nacional"50 que estabeleceu rumos para o planejamento da política cultural entre os anos de 1968-1971. Acumulava assim, desde os anos 1960, cargos disputados pela elite intelectual-burocrática do MEC e integrava as comitivas de discussões e coordenação de projetos diretivos das políticas culturais federais, sendo ele, evidentemente, uma figura chave nas redes de articulação das políticas culturais do período, que se moldaram com base nas concepções desenvolvimentistas e regionalistas do II PND. Soeiro esteve diretamente envolvido na estruturação e na implementação do PAC, assim como se manteve presente na criação, na implantação e na execução do PCH, como diretor do Iphan.

No cenário político e burocrático-administrativo apresentado, deu-se a iniciativa de criação do PCH, coordenada pelos Ministérios do Planejamento/ Seplan e da Educação e Cultura, em parceria com o Ministério do Interior por meio da Sudene e com o Ministério da Indústria e Comércio por meio da Embratur. Em janeiro de 1973, foi estabelecido um grupo de trabalho (GT) para estruturar o plano de ações para criação do PCH, composto por Renato Soeiro (MEC), Ney Tinoco (diretor da Embratur), Edileusa Rocha (Sudene), Affonso de Lima Vitule 
(Seplan), Fernando Quintela (Seplan - coordenador do GT) e Luiz Siqueira (Seplan - Secretário Executivo do GT). O PCH vinha concretizar metas e objetivos que foram referidos nos Compromissos de Brasília e de Salvador e incorporados na Política Nacional de Cultura, estabelecendo como principal filosofia de atuação a conciliação entre cultura e desenvolvimento.

Conforme analisado por Sandra Correa ${ }^{51}$, o trabalho coordenado e conjunto realizado por Augusto Carlos da Silva Telles (do Iphan) e Hélvio Polito (da Seplan) ${ }^{52}$ apresentou uma pré-seleção das cidades com potencial para o desenvolvimento do programa e, após uma jornada de diagnósticos territoriais com duração de aproximadamente 60 dias, o GT finalizou a seleção dos municípios ${ }^{53}$. $\bigcirc$ Relatório do GT indicava que, para manterem-se conservados, os monumentos históricos do Nordeste precisavam ter usos economicamente viáveis. Ao resolverem esse problema, poderiam atingir "a um dos principais objetivos do Governo, que é a geração de renda no Nordeste, como fruto dos benefícios esperados do incremento das atividades ligadas ao turismo a ser despertado na região." 54 . A associação entre patrimônio e turismo aparece como via natural de desenvolvimento regional naquele momento.

Em maio de 1973, João Reis Velloso e Jarbas Passarinho oficializaram a criação do PCH, reproduzindo o relatório final emitido pelo GT em abril do mesmo ano. As diretrizes centrais mencionadas acima conduziram as ações do PCH até 1977, quando o programa sofreu uma reformulação, ampliando os trabalhos em relação à abrangência territorial e às ações implementadas.

Na ata da reunião do Conselho Deliberativo da Sudene, de 19 de dezembro de 1973, verificamos o momento inicial de alguns convênios do PCH, contando com a presença dos ministros do Planejamento e da Indústria e Comércio, além de Luiz Siqueira, conselheiros, governadores, o presidente do BNDE, o coordenador do BNH e o Superintendente da Sudene:

Tomando a palavra o Presidente [do Conselho Deliberativo da Sudene] anuncia a assinatura de convênio entre o Ministério do Planejamento e os estados do Sergipe, Alagoas, Pernambuco, Rio Grande do Norte e Piauí, relativos ao Programa de Reconstrução das Cidades Históricas do Nordeste, e solicita ao Dr. Luís Siqueira que preste os esclarecimentos necessários. Informa então o Dr. Luís Siqueira que os convênios totalizam recursos da ordem de $\operatorname{Cr} \$ 400,0$ milhões, e se destinam à restauração de monumentos históricos, devendo os acordos serem celebrados entre o Ministério do Planejamento, Empresas de Turismo e os Presidentes de Fundações dos Estados já referidos ${ }^{55}$.

A presença de Velloso com representantes de cinco estados nordestinos, entre eles o Piauí, seu estado de origem, demonstrava que estava atento à implementação e ao desenvolvimento do programa, que foi concebido e executado sob a coordenação da Seplan. Os recursos financeiros vindos do Fundo de Desenvolvimento de Programas Integrados ${ }^{56}$ eram repassados da Seplan para o $\mathrm{PCH}$ e deste para o MEC, mais especificamente para o Iphan, como tratou Velloso:
51. Ver Sandra Rafaela Magalhães Correa (2012).

52. Augusto Carlos da Silva Teles foi arquiteto do Iphan e professor da Faculdade de Arquitetura e Urbanismo da UFRJ. Foi presidente da Fundação Nacional próMemória entre 1988-89. Hélvio Polito Lopes Filho é advogado, especialista em Conservação Urbana Integrada e mestre em Desenvolvimento Urbano. Atualmente, atua como Secretário Executivo de Meio Ambiente do Governo do Estado de Pernambuco.

53. Pré-lista de cidades apresentada pela Seplan: Cachoeira (BA); Salvador (BA); São Cristóvão (SE); Laranjeiras (SE); Penedo (AL); Marechal Deodoro (AL); Olinda (PE); Igarassu (PE); São Luís (MA); Alcântara (MA). Pré-lista apresentada pelo Iphan: Cachoeira (BA); Salvador (BA); Santo Amaro (BA); Jaguaribe (BA); Cariu (BA); Ilha de Itaparica (BA); Foz do Iguape (BA); Porto Seguro (BA); Lençóis (BA); Minas do Rio das Contas (BA); São Cristóvão (SE); Laranjeiras (SE); Tomar de Geru (SE); Penedo (AL); Marechal Deodoro (AL); Olinda (PE); Igarassu (PE); Itamaracá (PE); Guararapes (PE); Cabo de Santo Agostinho (PE); João Pessoa (PB); Cabedelo (PB). Cidades escolhidas para atuação do PCH: Cachoeira (BA); Salvador (BA); Santo Amaro (BA); Ilha de Itaparica (BA); Porto Seguro (BA); Lençóis (BA); São Cristóvão (SE); Laranjeiras (SE); Tomar de Geru (SE); Penedo (AL); Marechal Deodoro (AL); Porto Calvo (AL); Olinda (PE); Igarassu (PE); Itamaracá (PE); Guararapes (PE); Cabo de Santo Agostinho (PE); Goiana (PE); Paulista (PE); Vicência (PE); Cabedelo (PB); Natal (RN); Fortaleza (CE); Aracati (CE); Sobral (CE); Aquiraz (CE); Oeiras (PI); Piracuruca (PI). 
54. Ministério do Planejamento e Coordenação Geral apud Sandra Rafaela Magalhães Correa (2012, p. 129-130).

55. Cf. Arquivo Nacional, AC_ACE_19770_81. p.70

56. Segundo Henrique Oswaldo de Andrade, coordenador do $\mathrm{PCH}$ a partir de 1975, em entrevista à Sandra Rafaela Corrêa, o programa foi a primeira iniciativa a receber recursos desse fundo criado por João Paulo dos Reis Velloso. Ver Sandra Rafaela Magalhães Correa (2012).

57. Cf. Celso Castro; Maria Celina D'Araujo (2004, p.119).

58. Cf. Celso Castro; Maria Celina D'Araujo (2004, p. 207).

59. Ver Sandra Rafaela Magalhães Correa (2012).

60. Cf. entrevista concedida à Leila Bianchi Aguiar e Márcia Chuva em junho de 2013.

61. Em diversas atas do Conselho Consultivo do Iphan, entre 1970-1985, é possível verificar a resolução que recomenda que o processo de tombamento seja realizado pelos órgãos de preservação estaduais ou municipais. Também verificam-se menções relativas à participação das Diretorias Regionais em ações do instituto. Cf. Iphan. Ata do Conselho Consultivo do Iphan, fls 9898v. Rio de Janeiro, 13\04\1977. Ata do Conselho Consultivo do Iphan, fls 76v-77v. Rio de Janeiro, 07\02\1973. Ata do Conselho Consultivo do Iphan, fls 112v-114v. Rio de Janeiro, 12/01/1979.
(...) usamos alguns daqueles fundos para financiar projetos interessantes que iam aparecendo durante o exercício, inclusive na área de cidades históricas e projetos regionais (...) $\bigcirc$ coordenador foi Henrique Oswaldo e nós fornecíamos os recursos, que eram repassados ao então Ministério da Educação e Cultura ${ }^{57}$.

O caráter interministerial do $\mathrm{PCH}$ pode ser indício do lugar estratégico que ocupava no âmbito da vertente desenvolvimentista do regime, coadunando-se às diretrizes gerais para o desenvolvimento urbano prescritas no II PND, no qual foi apontado como um mecanismo de crescimento sociocultural em potencial. desenvolvimento cultural tornou-se um dos focos de investimento da política de planejamento orientada por João Paulo dos Reis Velloso, em que a revitalização de cidades históricas brasileiras, principalmente nordestinas, era avaliada como um projeto de infraestrtura urbana. Observemos, mais uma vez, a fala de Velloso:

Demos muita atenção ao desenvolvimento cultural, que, para nós, era parte do desenvolvimento tanto quanto o aumento do PIB. A mais importante iniciativa foi na área do patrimônio, com um programa de restauração de cidades históricas, primeiro para o Nordeste, depois para o Rio de Janeiro e Minas Gerais. É importante assinalar que tomamos a decisão de, em alguns casos, fazer a restauração de toda a cidade e não apenas de alguns monumentos. (...) Uma das coisas mais bonitas que vi na vida foi quando passei uma noite em Marechal Deodoro, Alagoas, à margem do São Francisco. Havia uma lua cheia, a cidade totalmente restaurada com lampiões de energia elétrica, mas que seguiam o modelo colonial. Esse programa compreendeu cerca de 100 projetos executados 58

Para Corrêa ${ }^{59}$, a parceria entre o Ministério do Planejamento e o Iphan não se deu de modo homogêneo e pacífico em todo período de existência do $\mathrm{PCH}$. Isso fica evidente com as avaliações formuladas por técnicos do Iphan, como Augusto da Silva Telles, após um ano de implementação do Programa. Foi nesse momento que Reis Velloso decidiu convidar o economista Henrique Oswaldo de Andrade, assessor de Élcio Costa Couto (secretário-geral da Seplan), para coordenar a iniciativa e reduzir seus entraves.

$\mathrm{Na}$ entrevista que realizamos com Antônio Carlos de Carvalho, ele comenta que Henrique Oswaldo de Andrade agregou força política ao PCH como um nome ligado ao ministro Velloso no programa: "Ele [Henrique Oswaldo de Andrade] era do Ministério do Planejamento. Fez parte do Programa de Cidades Históricas com a Briane [PanitzBicca]. Eles tinham uma força incrível. Ele era fantástico. Ele tinha muita força junto ao Reis Velloso"60.

Além de Henrique Oswaldo de Andrade, outro agente fundamental para o desdobramento do PCH foi o próprio Renato Soeiro, como diretor do Iphan. Soeiro participou ativamente do plano de descentralização, que em 1973 ainda mostrava-se tímido, incentivando a criação de órgãos de preservação do patrimônio cultural estaduais e municipais, a constituição de conselhos de cultura e a organização de diretorias regionais do Iphan, como pode ser conferido nas atas de reuniões do conselho consultivo do órgão ${ }^{61}$. Uma malha burocrática dedicada 
às políticas culturais na região nordestina foi estruturada para atender às normas dos convênios com o PCH, que condicionava a liberação de recursos apenas por meio de organismos culturais públicos ${ }^{62}$.

Essa política de descentralização, pulverizando pelos estados e municípios brasileiros instituições e legislações voltadas para a preservação dos bens culturais, atendia a diretrizes dos variados documentos mencionados anteriormente $^{63}$. Os governos locais eram incluídos nos projetos do $\mathrm{PCH}$ de maneira política, burocrática e orçamentária, comprometendo-se com 20\% dos custos, enquanto que o governo federal deveria fornecer os outros $80 \% 64$.

Durante o Regime Militar um amplo espectro de intelectuais com vínculos com elites culturais do Nordeste se aproximaram do projeto político desenvolvimentista do II PND e, a partir deles, representações acerca de uma identidade cultural (popular) nordestina ganharam caráter nacional.

Nesse cenário, o PCH fazia a sua parte. Pensado originalmente para atuar apenas na região Nordeste, o plano de ações para o estabelecimento do $\mathrm{PCH}$ dividiu o programa em duas fases. As cidades classificadas para a fase um seriam as que tivessem as melhores avaliações nos pontos ligados a infraestrutura física e turística, conforme os diagnósticos elaborados pela Embratur e pelo GT inicial do PCH. Antônio Carlos de Carvalho, na referida entrevista, lembra que participou da equipe que realizou diagnósticos de cidades que apresentavam potencial para o desenvolvimento do turismo e, de acordo com ele, o objetivo do trabalho era elaborar um "inventário turístico" dos locais. Ele conta que a Embratur desenvolveu uma série de estudos em diversas cidades nordestinas le posteriormente no Sudeste), em que equipes multidisciplinares de três a quatro técnicos - com formação em Ciências Humanas e Sociais - empregavam um questionário com muitos pontos de avaliação, preenchendo alguns tópicos com informações cedidas em entrevistas feitas com os gestores municipais e o restante provinha das observações da equipe. Ele conta:

Então, (...) eram dezenas de questões no diagnóstico do local histórico, não de conservação e preservação, mas de crescimento populacional, turismo, coisas diferentes... participação do rádio local, que é muito importante. Naquela época... isso é na época do Cidades Históricas.

(...) Aí, o que a gente pensava do turismo (...) tem o turismo, tem a demografia, conscientização da população local, que nós pesquisávamos pela Embratur e eu fui escrevendo sobre isso, fui tornando essas questões em parte redacional. Então, por exemplo, a gente perguntava: falta planejamento turístico em função do aproveitamento do local histórico?"65

turismo era visto como elemento-chave para viabilizar os objetivos do programa, pois, teoricamente, permitia o desenvolvimento urbano das cidades históricas em harmonia com as suas funções sociais. Uma das grandes questões apresentadas pelo setor do planejamento na década de 1970 era a ordenação do desenvolvimento urbano brasileiro, com vistas à desconcentração populacional
62. Ver Paulo Ormindo de Azevedo (2013).

63. Ver "Compromisso de Brasília”, em Iphan (1970); "Compromisso de Salvador", em Iphan (1973); "Política Nacional de Cultura: Diretrizes", em Conselho Federal de Cultura (1973).

64. Cf. Lia Calabre (2009).

65. Cf. entrevista concedida a Leila Bianchi Aguiar, Márcia Chuva e Laís Lavinas em junho de 2013. 
66. Cf. SEPLAN (1974, p.68).

67. Cf. SEPLAN (1974, p.69).

68. Aloisio Magalhães era designer gráfico, tendo atuado em diversas instâncias do Estado autoritário durante o regime militar, até assumir a direção do Centro Nacional de Referências Culturais. Em 1979, tornou-se presidente do Iphan finalizando a reforma administrativa no campo patrimonial iniciada na gestão de Renato Soeiro. Permaneceu à frente do instituto até sua morte, em 1982.

69. De acordo com o Deputado Fernando Coelho, a Comissão Parlamentar de Inquérito do Patrimônio (1981) foi proposta pela Resolução ${ }^{\circ} 78$, de 1979, e se destinava a "investigar a situação do Patrimônio Histórico e Artístico Nacional e a avaliar a política do Governo Federal para a sua defesa e conservação". Ver Câmara dos Deputados (1981).

70. Cf. Câmara dos Deputados (1981, p. 39-40). do Sudeste, por meio do planejamento urbano das cidades das outras regiões, especialmente no Centro-Oeste e Nordeste. Esse debate já aparecia no I Plano Nacional de Desenvolvimento (I PND), instituído no governo Médici (1972-1974) e, em relação às cidades históricas, foi abordado nos dois Encontros de Governadores, ocorridos em 1970 e 1971, referidos anteriormente. No II PND (1974-1979), essas questões tornaram-se tema da segunda parte do plano, em que a cidade era o ponto de partida para o planejamento do desenvolvimento regional e nacional: "A cidade irá, então, situar-se dentro do planejamento do pólo econômico em que se encontra, definindo-se a sua função econômica e social e, só então, passando a definir-se sua configuração físico-urbanística"66. A associação entre turismo, desenvolvimento e preservação cultural foi apresentada no II PND como uma estratégia de urbanização apropriada para a orla marítima nordestina:

Na região Nordeste a estratégia urbana procurará alcançar: (...) A ordenação da ocupação da orla marítima, preservando-se o patrimônio histórico e valorizando-se a beleza paisagística, com vistas ao desenvolvimento do turismo interno e internacional ${ }^{67}$.

PCH planejava dar conta da revitalização urbana por meio da restauração arquitetônica em cidades históricas e do fomento ao desenvolvimento socioeconômico. Esse se daria com a exploração dos aspectos culturais dos municípios para geração de renda e sua realização por meio do incentivo ao turismo. Sua ação direcionada para a Região Nordeste acabou por evidenciar diversos bens culturais que ainda não haviam sido salvaguardados pelo lphan. Portanto, entre 1975 e 1979, vê-se o redirecionamento da atuação institucional para a Região Nordeste, região também focada na gestão seguinte, de Aloísio Magalhães ${ }^{68}$, a partir de 1979, mesmo ano em que uma Comissão Parlamentar de Inquérito do Patrimônio Cultural para "investigar a situação do Patrimônio Histórico e Artístico Nacional e avaliar a política do Governo Federal para a sua defesa e conservação" foi estruturada69. Em seu depoimento à CPI, Magalhães citava o PCH como um mecanismo de viabilização da descentralização das políticas patrimoniais. Além disso, Magalhães associava as ações do PCH com a promoção do turismo local e a melhoria no cuidado com os bens culturais:

A ideia de descentralização, no que se refere a patrimônio, no seu sentido mais clássico, vem desde 1973, creio, com a criação, pelo Ministro Velloso, de um programa específico para proteção do bem cultural nas cidades históricas do Nordeste. Veio pelo filão econômico, em parte, a ideia de que, se revitalizarmos certas áreas do Nordeste, ao nível de seu valor histórico, nós poderíamos ter maior turismo, fluxo de interesses, etc. (...) Esse programa tem realizado um trabalho extraordinário nesses oito anos de existência, porque, na verdade, ele inaugurou dentro do sistema antigo IPHAN a descentralização. (...) A descentralização é notável, porque estimulou os estados, e já agora os municípios, criassem suas estruturas de proteção do meio cultural, com legislação específica, com quadro de competência ${ }^{70}$. 
Se o turismo era um forte viés da política cultural ligada ao projeto desenvolvimentista do Estado autoritário brasileiro, outro agente fundamental nessa rede de relações e de poder foi Severo Gomes, Ministro da Indústria e Comércio do governo Geisel, ministério ao qual a Embratur era ligada. Na introdução da publicação da entrevista realizada com o ex-presidente Ernesto Geisel, Castro e D'Araújo afirmam que há muito tempo Severo Gomes integrava debates reflexivos sobre a força e a identidade do produto cultural brasileiro, tendo bom alcance político-territorial entre grupos de esquerda. Segundo eles, o ministro era considerado, pelo próprio presidente, um ultranacionalista e empenhava-se em projetos públicos de estímulo ao desenvolvimento socioeconômico e cultural autônomo do Brasil ${ }^{71}$.

Em 1976, a Revista Visão ${ }^{72}$ publicou uma síntese da entrevista concedida pelo Ministro da Indústria e Comércio Severo Gomes com o título "Para a defesa da cultura brasileira". Severo Gomes contava que, ao assumir o ministério em 1974, deu prosseguimento político à sua ideia de criar um programa para estimular o desenvolvimento do desenho industrial no país, de forma a identificar o produto cultural brasileiro. Havia procurado o embaixador Wladimir Murtinho que o recomendou o nome de Aloísio Magalhães para pensar na organização de um centro dinâmico de pesquisas sobre a cultura brasileira. Desse contato surgiu o Centro Nacional de Referência Cultural (CNRC), em 197573. A matéria na revista Visão gerou visibilidade para o CNRC entre os grupos sociais ligados ao setor cultural, em parte, graças à posição assumida por setores do governo federal em relação à nova iniciativa na área pública cultural. Severo Gomes utilizou-se do espaço da revista para buscar consenso em torno da criação do novo centro, afirmando que o seu ministério "dispõe de razões de sobra para aplicar nesse projeto, não é o mecenato que o move".

Antônio Carlos de Carvalho conta como percebia a concepção de patrimônio cultural de Severo Gomes e menciona a força do debate patrimonial na concepção das políticas públicas de turismo:

(...) o primeiro Plano Nacional de Turismo de 1966 falava largamente do patrimônio histórico. Mais ainda o de 1977, que foi feito pelo Francisco Manuel de Melo Franco ${ }^{74}$, que era diretor de Planejamento da Embratur, ligado ao Severo Gomes. (...) Esse ministro da Indústria e Comércio era fantástico. Definiu em um seminário o conceito de patrimônio: "é tudo aquilo feito pelos brasileiros". Eu achei aquilo fantástico. (...) Maravilhoso isso, né?75

Já comentamos o papel de Afonso Arinos como agente-chave no (e para) o setor político-cultural desde o fim dos anos 1940. Destacamos então a amplitude das redes de agentes que interligavam setores econômicos brasileiros (público e/ ou privado) e a área da política cultural que se delineava, reforçando seu alcance nos planos de ações desenvolvimentistas do regime militar. Nessas redes, os ministros João Reis Velloso e Severo Gomes formaram alianças importantes como agentes públicos e privados, ligados à vertente desenvolvimentista do regime e integraram o Conselho de Desenvolvimento Econômico (CDE), criado por Ernesto
71. Ver Celso Castro; Maria Celina D'Araujo (1997).

72. A revista Visão pertencia ao empresário do ramo turístico, Said Farhat, que foi presidente da Embratur entre 1975-1979 Ver: Ernani Teixeira Filho (1976).

73. Para o assunto, ver Laís Villela Lavinas (2014).

74. Francisco Manuel de Melo Franco, filho de Afonso Arinos, formou-se em Engenharia Civil na PUC Rio, em 1956, e era também escritor. Em 1993, tornou-se presidente Instituto Brasileiro de Patrimônio Cultural, denominação do Iphan na época.

75. Cf. entrevista concedida a Leila Bianchi Aguiar, Márcia Chuva e Laís Lavinas em junho de 2013. 
76. O CDE era formado pelos Ministros da Fazenda (Mário Henrique Simonsen), do Planejamento (João Reis Velloso), da Indústria e Comércio (Severo Gomes $\backslash$ Ângelo Calmon), de Minas e Energia (Shigeaki Ueki), do Interior (Rangel Reis) e da Agricultura (Alysson Paulinelli) e, de acordo com Velloso, reunia-se toda quarta-feira, às $10 \mathrm{~h} \mathrm{da}$ manhã. Ver Celso Castro; Maria Celina D'Araujo (2004).

77. Ver Sandra Rafaela Magalhães Correa (2012).

78. Ver Márcia Sant'Anna (1995).
Geisel, por sugestão de João Reis Velloso, com a finalidade de reunir o presidente e todos os ministros do setor econômico pelo menos uma vez por mês ${ }^{76}$.

No âmbito dessa imbricada rede de poder em que se inscrevem também as políticas culturais, o PCH consistia em um projeto de ações integradas entre três ministérios do setor econômico e um do setor social. Por meio da identificação dessas redes de interesses comuns, é possível verificar amplitude política do programa e o processo histórico em que se deu a naturalização da associação entre turismo e patrimônio.

Em 1980, foi publicado o livro Proteção e revitalização do patrimônio histórico e artístico nacional: uma trajetória, pela Fundação Nacional PróMemória, dirigida então por Aloísio Magalhães, que inaugurou a produção historiográfica acerca da história da preservação do patrimônio cultural no Brasil. Nessa publicação, é apresentada uma periodização em duas grandes fases, assim denominadas: a "fase heróica", que englobaria todo o período da gestão de Rodrigo Melo Franco de Andrade e também a gestão de Renato Soeiro; e a "fase moderna", que teria se iniciado com a gestão de Aloísio Magalhães. $\bigcirc$ livro teve uma importância considerável nos anos 1980, por construir e divulgar uma história institucional em meio às grandes mudanças ocorridas, como a criação da Fundação Nacional pró-Memória, vinculada ao Iphan, e a incorporação do CNRC e do PCH ao instituto. Evidentemente, essa incorporação não se deu sem disputas pela hegemonia no interior da própria agência e a referida publicação revela a visão do grupo que se torna hegemônico naquele momento, colocando em destaque a força política de Aloísio Magalhães, e obscurecendo a gestão de Renato Soeiro e seu papel fundamental nas grandes transformações que se processavam na instituição, no Brasil e no mundo em relação ao patrimônio cultural.

Essa perspectiva se reproduziu tornando-se hegemônica e foi incorporada de tal modo que poucos estudos hoje a questionam e a maioria deles acaba por reproduzi-la sem interrogações. Essa divisão - tecida em um contexto muito específico - revela as lutas institucionais, intraburocráticas que se processavam na virada dos anos 1970 para os anos 80. Nesse sentido, a historiografia do campo do patrimônio brasileiro pouco contribuiu para um olhar crítico sobre os anos 1970 e seus principais agentes nos campos cultural e do patrimônio.

Embora muito citado em estudos do campo do patrimônio cultural, somente nos últimos anos o PCH tem se tornado, ele próprio, objeto de investigação, como na análise de Sandra Correa ${ }^{77}$ sobre as relações de poder na implantação e na execução do PCH e a constituição de um Sistema Nacional de Preservação do Patrimônio Cultural. Para ela, e em acordo com Márcia Sant'Anna, o Iphan saiu reforçado daquele contexto, com o seu reconhecimento como lócus para políticas de preservação e com uma rede de novas agências locais e estaduais de cultura e patrimônio, desconstruindo-se a ideia de que o órgão estava enfraquecido, decadente e esvaziado ao final da gestão de Renato Soeiro ${ }^{78}$. 
Para nossa análise, fizemos contato com memórias de protagonistas do alto escalão do regime e de técnicos que compartilharam vivências, relacionadas à conjuntura e ao próprio PCH que, de algum modo, iluminaram a diversificada documentação com elas aqui cotejada. Com esse exercício, buscamos evidenciar o processo de incorporação do campo da cultura nos meandros da política nacional mais ampla e, especialmente, o papel desempenhado pelo PCH nesse sentido. Sua formulação, em vários aspectos, o caracteriza como um programa estratégico na política integradora e desenvolvimentista do regime: seu caráter interministerial; o foco na Região Nordeste e a exigência de medidas descentralizadoras para sua execução. E, ainda, as diretrizes indutoras da revitalização urbana e da estruturação de serviços turísticos nas cidades que receberiam financiamento para as ações do PCH. Todos esses aspectos foram regidos - não sem conflitos - sob a batuta da área de preservação patrimonial, tendo em vista que a agência pública responsável pela sua execução era o Iphan que, posto então em xeque, acabou sendo fortalecido.

Os intelectuais envolvidos com o PCH não diferem integralmente da intelectualidade que estava presente no âmbito das agências e fóruns de cultura desde os anos do governo Vargas. Parcerias historicamente delineadas pelas elites se reproduziram nesse contexto, envolvendo intelectuais burocratas ligados a agências públicas do campo da cultura, da educação e das relações exteriores. Práticas políticas incorporadas como habitus ${ }^{79}$ se reproduziam, tendo em vista que permanecia a crença moderna na necessidade de educar o cidadão para usufruir da cultura. Ainda assim, tais redes diferiram parcialmente (ou ampliaram-se), pois uma intelectualidade ligada às elites políticas e culturais de estados do Nordeste passou a ocupar postos de poder, cargos de prestígio nesse contexto de reinvenção ou renomeação dos valores da brasilidade. Somados a eles, novas redes de agentes ligadas aos setores econômicos públicos e/ou empresariais acabaram por complexificar o campo cultural e do patrimônio cultural e também as lutas de representação acerca dos sentidos da brasilidade.

Sem dúvida, o PCH é um dos grandes responsáveis pela consagração da conexão mais expressiva então estabelecida entre turismo e preservação cultural, de tal modo explorada que passou a ser reconhecida como a saída natural para o desenvolvimento de regiões históricas empobrecidas. Essa associação, reproduzida nos diferentes documentos da época, foi fruto da atuação política de intelectuais burocratas, empresários, técnicos e profissionais de vários setores inseridos nas agências do Estado, e promoveu a incorporação das políticas culturais nas políticas nacionais de desenvolvimento social. Sua naturalização, contudo, impossibilitou a busca de estratégias alternativas mais inclusivas e menos submetidas a demandas empresariais do turismo, em boa medida subsidiadas /pelo menos indiretamente) pelo desenvolvimentismo, e com presença marcante, ainda hoje, nas políticas públicas de patrimônio cultural.
79. Como proposto por Pierre Bourdieu (1982), habitus como um conjunto de práticas incorporado e compartilhado pelo pertencimento institucional, que se constitui também em mecanismo de prestígio, reconhecimento e promoção. 
Embora naturalizada, tal associação não é inexorável e outras estratégias podem ser pensadas para o patrimônio e a sustentabilidade das populações caminhos diversificados para aqueles que não têm que ser ensinados.

Um novo Iphan surgiu daquele contexto, reconhecido como lócus para políticas públicas de preservação e com uma rede de novas agências locais e estaduais de cultura. Uma política de patrimônio integrada ao novo Estado se reorganizou no processo de redemocratização sob a égide capitalista.

Integrante do processo de complexificação do campo cultural, esse Estado passa a promover políticas públicas que levam à incorporação da cultura popular como espetáculo. Mais do que medidas voltadas para a construção de uma imagem mais branda do regime, vale pensar nessas políticas culturais associadas ao desenvolvimento moderno, em que o PCH se insere como uma linha de políticas públicas fundada na apropriação do conceito de democracia conforme apontado aqui - como acesso aos bens culturais que são oferecidos le apenas esses).

O momento de significativas viradas no campo do conhecimento das Ciências Sociais, em que se colocou em xeque esse pensamento moderno, lamentavelmente, não redundou na derrubada de sua hegemonia. Nesse contexto, surgem importantes críticas e são também (re)formuladas as teses neoliberais - cuja ideia da liberdade não viabiliza a superação da linha abissal, ao contrário, acaba por reforçar o silêncio com base na reinvenção da legitimidade da "livre iniciativa". 


\section{REFERÊNCIAS}

FONTES PRIMÁRIAS

Arquivo CNV (Comissão Nacional da Verdade), Brasília.

00092.000097/2014-82. Diretriz de Segurança Interna, 1968.

00092.000775/2012-45. Ligações Funcionais dos Órgãos do Sistema Setorial de Informações do Ministério da Educação e Cultura - Normas Reguladoras - $n^{\circ} 1 / 77$ - Documento assinado por Armando Menezes, diretor da DSI/MEC, 1977.

Arquivo Nacional, Rio de Janeiro

AC_ACE_19770_81. Depoimento à CPI Quatro Rodas Hotéis do Nordeste - Dr. Rubens Vaz da Costa, 1981.

BR_AN_BSB_AA1_LGS_018. Diário Oficial da União de 16 de abril de 1969, seção I, parte I. Apresenta o regimento da Divisão de Segurança e Informações do MEC.

BR_DFANBSB_2M_0_0_0497_0002_d0001de0001. Documentos Recebidos na PR/EMFA durante o terceiro semestre de 1967. 1967.

Arquivo do Iphan, Rio de Janeiro

Ata do Conselbo Consultivo do IPHAN, fls 76v-77v. 07/02/1973.

Ata do Conselbo Consultivo do IPHAN, fls 98-98v. 13/04/1977.

Ata do Conselho Consultivo do IPHAN,fls 112v-114v. 12/01/1979. Disponível em: <http:// portal.iphan.gov.br/atasConselho?data=1971\%2F1980>, acesso em: 10 de julho de 2013.

Ata do Conselbo Consultivo do IPHAN. 1968-1982. Disponível em: <http://portal.iphan.gov.br/ atasConselho>, acesso em: 10 de julho de 2013.

Compromisso de Brasília. In: Encontro de Governadores. Departamento de Assuntos Culturais. Brasília, 1970.

Compromisso de Salvador. In: II Encontro de Governadores para Preservação do Patrimônio Histórico, Artístico, Arqueológico e Natural do Brasil. Departamento de Assuntos Culturais, 1971, Rio de Janeiro. Anais... Rio e Janeiro, 1973.

Fundação Joaquim Nabuco, Recife

Arquivo Persona Aloísio Magalhães (APAM). Referência PIp15doc73c.

Annals of Museu Paulista. v. 24. n.1. Jan.-Apr. 2016. 
TEIXEIRA FILHO, Ernani. Correspondência Passiva com Aloísio Magalhães. Brasília, 1976. Referência: CP p6 doc106 - A 11g 2. APAM-FUNDAJ. (Fotocópia da matéria da Revista Visão "Para a defesa da cultura brasileira", entrevista com Severo Gomes).

\section{LIVROS, TESES, PERIÓDICOS E ANAIS}

AGUIAR, Leila Bianchi. Turismo e preservação nos sítios urbanos brasileiros: o caso de Ouro Preto. 2006. Tese (Doutorado em História) - Universidade Federal Fluminense, Niterói, 2006.

ALBUQUERQUE JÚNIOR, Durval Muniz. A invenção do Nordeste e outras artes. São Paulo: Cortez, 2009.

AZEVEDO, Paulo Ormindo de. Renato Soeiro e a institucionalização do setor cultural no Brasil. In: AZEVEDO, Paulo Ormindo; CORRÊA, Elyane Lins (org.). Estado e sociedade na preservação do patrimônio. Salvador: EDUFBA; IAB, 2013, p. 19-54.

BRAGA, Ney. Discurso. Boletim do Conselbo Federal de Cultura, Rio de Janeiro, n. 23, páginas 22-23, 1976.

BRASIL. PRESIDÊNCIA DA REPÚBLICA. Secretaria de Planejamento. II Plano Nacional de Desenvolvimento. Brasília, 1974. Disponível em: http://www.planalto.gov.br/ccivil_03/ leis/1970-1979/anexo/ANL6151-74.PDF, acesso em 5 de novembro de 2013.

BRASIL. MINISTÉRIO DE EDUCAÇÃO E CULTURA. Secretaria da Cultura. Definições para a Operacionalização da Política Cultura. Brasília, 1981.

BRASIL. MINISTÉRIO DE EDUCAÇÃO E CULTURA. Secretaria da Cultura. Documento apresentado pelo Secretário de Cultura na Reunião de Coordenação Geral do MEC. Brasília, abril, 1981.

BOURDIEU, Pierre. A economia das trocas simbólicas. São Paulo: EDUSP, 1982.

O poder simbólico. São Paulo: DIFEL, 1989.

CALABRE, Lia. Políticas culturais no Brasil: dos anos 1930 ao século XXI. Rio de Janeiro: Editora FGV, 2009.

CÂMARA DOS DEPUTADOS. Comissão Parlamentar de Inquérito destinada a investigar a situação do Patrimônio Histórico e Artístico Nacional e Avaliar a Política do governo federal para sua defesa e conservação. Relatório. Brasília, 1981.

CANCLINI, Nestor. G. Definiciones en transición. In: MATO, Daniel; ARIZPE, Lourdes (org.) Estudios latinoamericanos sobre cultura y transformaciones sociales en tiempos de globalización. Buenos Aires: Clacso, 2001, p. 57-68.

CARVALHO, Antônio Carlos de. Relato da experiência de trabalho na Embratur nos anos 1970. Rio de Janeiro, Programa de Pós-graduação em História Social da Universidade Federal do Estado do Rio de Janeiro, junho de 2013. Entrevista a Leila Bianchi Aguiar, Márcia Chuva e Laís Villela Lavinas. 
CASTRO, Celso; D’ARAuJO, Maria Celina (org.). Ernesto Geisel. Rio de Janeiro: Editora Fundação Getúlio Vargas, 1997.

CASTRO, Celso; D'ARAUJO, Maria Celina. Tempos modernos: João Reis Veloso, memória do desenvolvimento. Rio de Janeiro: Editora FGV, 2004.

CHUVA, Márcia. Os arquitetos da memória: sociogênese das práticas de preservação do patrimônio cultural no Brasil (anos 1930-1940). Rio de Janeiro: Editora UFRJ, 2009.

.Por uma história da noção de patrimônio cultural no Brasil. Revista do Patrimônio Histórico e Artístico Nacional, Brasília, n.34, p. 147-165, 2011.

COHN, Gabriel. A concepção oficial da política cultural dos anos 70. In: MICELI, Sergio (org.). Estado e cultura no Brasil. São Paulo: Difel, p.85-96, 1984.

CONSELHO Federal de Cultura. Política Nacional de Cultura: diretrizes. Rio de Janeiro, 1973.

CONSELHO Federal de Cultura. Política Nacional de Cultura. Rio de Janeiro, 1975.

CORREA, Sandra Rafaela Magalhães. O Programa de Cidades Históricas (PCH): por uma política integrada de preservação do patrimônio cultural - 1973/1979. 2012. Dissertação (Mestrado em Arquitetura e Urbanismo) - Universidade de Brasília, Brasília, 2012.

DIAS, Caio Gonçalves. Da “Antropologia Filosófica" ao "Do-In Antropológico": um estudo crítico da ideia de políticas culturais no Brasil (1985-2013). 2014. Tese (Doutorado em Antropologia Social) - Museu Nacional/UFRJ, Rio de Janeiro, 2014.

ELIAS, Norbert. O processo civilizador: formação do Estado e Civilização. Rio de Janeiro: Jorge Zahar Ed., 1993, v.2.

FICO, Carlos. Reinventando o otimismo: ditadura, propaganda e imaginário social no Brasil. Rio de Janeiro: Editora Fundação Getúlio Vargas, 1997.

Versões e controvérsias sobre 1964 e a ditadura militar. Revista Brasileira de História, São Paulo, v.24, n.47, p. 29-60, 2004.

FONSECA, Maria Cecília Londres. O patrimônio em processo - trajetória da política federal de preservação no Brasil. Rio de Janeiro: UFRJ-Iphan, 1997.

GOMES, Angela de Castro. A política brasileira em busca da modernidade: na fronteira entre o público e o privado. In: SCHWARCZ, Lilia Moritz (org.). História da vida privada no Brasil, 4: contrastes da intimidade contemporânea. São Paulo: Companhia das Letras, 1998, p.490-558.

GONÇALVES, José Reginaldo. Autenticidade, memória e ideologias nacionais: o problema dos patrimônios culturais. Estudos Históricos, Rio de Janeiro, v.1, n. 2, p. 264-275, 1988.

- A retórica da perda: os discursos do patrimônio cultural no Brasil. Rio de Janeiro:

Editora UFRJ, 1996.

GRAMSCI, Antonio. O leitor de Gramsci: escritos escolhidos 1916-1935. Organização e Introdução de Carlos Nelson Coutinho. Rio de Janeiro: Civilização Brasileira, 2011.(Leitores). 375p. 
LAVINAS, Laís Villela. Um animal político na cultura brasileira: Aloísio Magalhães e o campo do patrimônio cultural no Brasil (anos 1966-1982). 2014. Rio de Janeiro: Dissertação (Mestrado em História) - Universidade Federal do Estado do Rio de Janeiro, Rio de Janeiro, 2014.

MAIA, Tatyana de Amaral. A construção do "senado da cultura nacional" em tempos autoritários (1967-1975). Rio de Janeiro: Fundação Biblioteca Nacional/MinC, 2010.

Os cardeais da cultura nacional: o Conselho Federal de Cultura na ditadura civil-militar (1967-1975). São Paulo: Itaú Cultural; Iluminuras, 2012.

MICELI, Sérgio. Intelectuais e classe dirigente no Brasil (1920-1945). São Paulo: Difel, 1979.

Teoria e prática da política cultural oficial no Brasil. In: MICELI, Sérgio (org.). Estado e cultura no Brasil. São Paulo: Difel, 1984, p.97-111.

MOTTA, Rodrigo Patto Sá. As universidades e o regime militar. Cultura política brasileira e modernização autoritária. Rio de Janeiro: Zahar, 2014.

PARREIRA, Roberto. Depoimento. In: MICELI, Sérgio (org.). Estado e cultura no Brasil. São Paulo: Difel, 1984, p.223-240.

SANT'ANNA, Márcia. Da cidade-monumento à cidade-documento: A trajetória da norma de preservação de áreas urbanas no Brasil (1937-1990). 1995. Dissertação (Mestrado em Arquitetura e Urbanismo) - Universidade Federal da Bahia, Salvador, 1995.

SANTOS, Boaventura de Sousa. Para além do pensamento abissal: das linhas globais a uma ecologia de saberes. Revista Crítica de Ciências Sociais, Coimbra, n.78, p. 3-46, out. 2007.

SILVA, Francisco Carlos Teixeira. A modernização autoritária: do golpe militar à redemocratização (1964/1984). In: LINHARES, Maria Yedda (org.). História Geral do Brasil. 9 ed. Rio de Janeiro: Campus, 2000, p.301-333.

Artigo apresentado em 20/01/2016. Aprovado em 31/05/2016. 